\title{
IDENTIFICATION AND ANTIMICROBIAL SUSCEPTIBILITY TESTING OF PATHOGENIC MICRO-ORGANISM FROM DENTAL PATIENTS
}

\section{SAKTHIVEL M ${ }^{1}$, AYYASAMY PMㄹ , ARVIND PRASANTH D1*}

Department of Microbiology, School of Biosciences, Periyar University, Salem - 636 011, Tamil Nadu, India. Email: prasanthviji@gmail.com Received: 24 June 2016, Revised and Accepted: 07 July 2016

\section{ABSTRACT}

Objective: To isolate and identify aerobic microbes present in the periodontal infected patients and to evaluate the choice of antibiotics in the management of periodontal diseases.

Methods: In this study, these patients have not been treated previously for their conditions. An informed consent was obtained from these patients before collection of an oral swab. This study was approved by the Institutional Ethical Committee. The details of the patient's age, sex, and clinical details were recorded on a per forma meant for this study. The following methodologies were adopted for the isolation and identification of the microorganisms from these cases.

Results: In this study out of 50 oral samples, culture positivity was recorded in 43 (86\%) cases and no growth in 7 (14\%) cases. Antibiotic susceptibility test using to identified as resistant, sensitive, intermediate of pathogenicity of oral microbes. Such antibiotics were methicillin, ceftazidime, clindamycin, amikacin, cloxacillin, and cefotaxime. This study should be kept in mind when a local application of antibacterial compounds is used in the therapy of periodontal disease.

Conclusion: This study highlights the different organisms involved in the different types of dental infections. The antibiotic pattern shown in this work will be a guide to the clinician in the selection of proper antibiotics for the treatment of these infections. Hence in this study, the limitations were time and the number of patients. For better outcomes, a larger study population for a longer period of time should be undertaken to know the bacteriology and to the select the effective drugs of choice for dental infections. A comparative study of bacteriology and mycology and its antimicrobial property would be very fruitful in the future.

Keywords: Dental, Periodontal, Bacteria, Antibiotics.

(C) 2016 The Authors. Published by Innovare Academic Sciences Pvt Ltd. This is an open access article under the CC BY license (http://creativecommons. org/licenses/by/4. 0/) DOI: http://dx.doi.org/10.22159/ajpcr.2016.v9s2.13668

\section{INTRODUCTION}

Teeth is a hard, resistant structure occurring on the jaws in or around the mouth and pharynx areas of vertebrates used for catching and masticating food, for defense, and for other specialized purposes [1] A tooth consists of a crown and one or more roots. The crown is the functional part that is visible above the gum [2]. The root is the unseen portion that supports and fastens the tooth in the jawbone [2] The microbial floras of the oral cavity are rich and extremely diverse. This reflects the abundant nutrients and moisture, hospitable temperature, and the availability of surfaces on which bacterial populations can develop. Over 500 bacterial species have been identified from the human oral cavity [3] but with the exception of a limited number of pathogens the majority of them are considered to be benign or beneficial. Micro-organism such as Streptococcus, Actinomyces, Neisseria, and Veillonella present as primary colonizers while Fusobacterium nucleatum and Capnocytophaga species occur as secondary colonizers $[4,5]$. The main objective of the current study is to isolate and identify aerobic microbes present in patients with different dental infections and to evaluate the choice of antibiotics in the management of these dental infections. The results of this study will be useful for the clinician in the selection of appropriate antibiotics for treatment and prevent the phenomena of drug resistance in the micro-organism.

\section{METHODS}

\section{Sample collection}

Over a period of 3-month from January 8, 2013, to April 8, 2013 , a total of 50 patients presenting in the outpatient unit of Nataraja Dental College, Komarapalayam, Namakkal, Tamil Nadu, were enrolled in this study. These patients have not been treated previously for their conditions. An informed consent was obtained from these patients before the collection of an oral swab. This study was approved by the Institutional Ethical Committee for the enrollment of human subjects. The patient's details - namely age, sex, and clinical details - were recorded on a per forma exclusively meant for this study. The following methodologies were adopted for the isolation and identification of the micro-organisms from these cases. Two swabs were taken for each patient from the Kumaramangalam region by the medical doctor.

\section{Isolation and identification of pathogens}

The oral swabs were inoculated onto the plate of nutrient agar and Sabouraud dextrose agar plate. The bacterial plates were incubated at $37^{\circ} \mathrm{C}$ for $24 \mathrm{hrs}$. The fungal plates were incubated at $27^{\circ} \mathrm{C}$ to $30^{\circ} \mathrm{C}$ for 48-72 hrs. Significant growth of the culture was interpreted as positive for microscopy with the growth of the same organism in culture in more than one medium. The identification of the bacterial isolates was based on the standard methods [6].

\section{Antibiotic susceptibility test}

The antibiotic susceptibility tests of the bacterial isolates were done following the method of Kirby-Bauer disc diffusion method [7]. The sterilized nutrient broths were prepared, and the bacterial isolates were inoculated and incubated at $37^{\circ} \mathrm{C}$ for $1-2$ hrs. The bacterial culture was made into a thin suspension and was plated onto plates of Muller-Hinton agar using a sterile cotton swab and spreading it in all the directions over the surface of the agar to obtain a uniform growth. The antibiotic disc was placed over the agar and incubated at $37^{\circ} \mathrm{C}$ for $24 \mathrm{hrs}$. The diameter of the zone of inhibition was measured around each disc and interpreted using the standard chart. 


\section{RESULTS}

Over a period of 3-month from January 2013 to April 2013, a total of 50 oral swab samples were collected from the patients presenting at the outpatient unit of Nataraja Dental College, Komarapalayam, Namakkal, Tamil Nadu, India. The oral swabs were taken to the medical laboratory and investigated for both bacteria and fungi. Out of 50 oral samples, culture positivity was recorded in $43(86 \%)$ cases and no growth in $7(14 \%)$ cases. There was a mixed bacterial infection in $11(22 \%)$ cases. Along with bacterial isolates, yeast species were also identified in $10(20 \%)$ cases. Of the 43 culture positive cases, Gram-positive bacteria were found to be high 38 (88.37\%) isolates, followed by Gram-negative bacteria as $17(39.53 \%)$ isolates and yeast for $10(23.25 \%)$ cases which were speciated by Hi-chrome Candida agar. The patient's demographic details were tabulated in Table 1.

\section{Distribution of gender}

Among 50 patients, 27 (54\%) were males and 23 (46\%) were females. The male:female ratio was found to be 1.17:1. Hence, male patients were highly susceptible to oral infections than females.

\section{Distribution of types of dental infections}

The pattern of patient's distribution of different types of dental infection included $34(68 \%)$ patients with periodontal infections followed by carries $10(20 \%)$ patients with mild to moderate condition, $3(6 \%)$ patients who had undergone root canal treatment, pulpitis, malocclusions, and root stump patients with each 1 case (2\%), respectively. In this distribution, it was found that patients with periodontal infection were found to be higher than any other oral infections (Fig. 1).

\section{Age wise distribution pattern of dental infections}

The most predominant age group was 21-30 years accounting for $16(32 \%)$ cases, followed by the age group of 31-40 years. The major reason attributing to such a cause is improper tooth care, smoking and usage of carbonated drinks (Fig. 2).

\section{Growth pattern of bacterial isolates in dental infections}

The Gram-positive cocci accounting for 22 (41\%) cases showed a higher predominance followed by Gram-negative bacilli which was found as 17 (29\%) cases (Fig. 3).

\section{Bacterial distribution among dental infections}

Altogether, 55 bacterial isolates were obtained from 50 samples of different oral infections. The most frequent and predominant bacteria associated with the oral infections were Bacillus spp. in 16 (29\%) cases, followed by Micrococcus spp. in 12 (22\%) cases. The predominant Gram-negative organism was Pseudomonas aeruginosa in 9 (16\%) cases, followed by Klebsiella spp. in 7 (13\%) cases (Fig. 4).

\section{Fungal distribution among dental infections}

Along the fungal isolates, Candida spp. was isolated in 10 (20\%) cases. Of the various candida species, Candida albicans was the predominant one isolated and confirmed in this study.

\section{Antibiotic sensitivity pattern}

The antimicrobial susceptibility pattern showed Staphylococcus aureus as $100 \%$ sensitive to methicillin, ceftazidime, clindamycin, amikacin, cloxacillin, and cefotaxime, whereas Bacillus spp. was resistant to cloxacillin. Micrococcus spp. showed resistant to both cloxacillin and clindamycin. Gram-negative isolates, Klebsiella spp. and Pseudomonas spp., were highly resistant to clindamycin, cloxacillin, and tetracycline but sensitive to amikacin (Table 2).

\section{DISCUSSION}

Oral infections (dental caries, periodontal disease, and gingivitis) were the most common chronic oral disease in the world. Bacterial dental plaque was considered to be the primary etiological factor in the development of dental caries, gingivitis, and periodontitis.

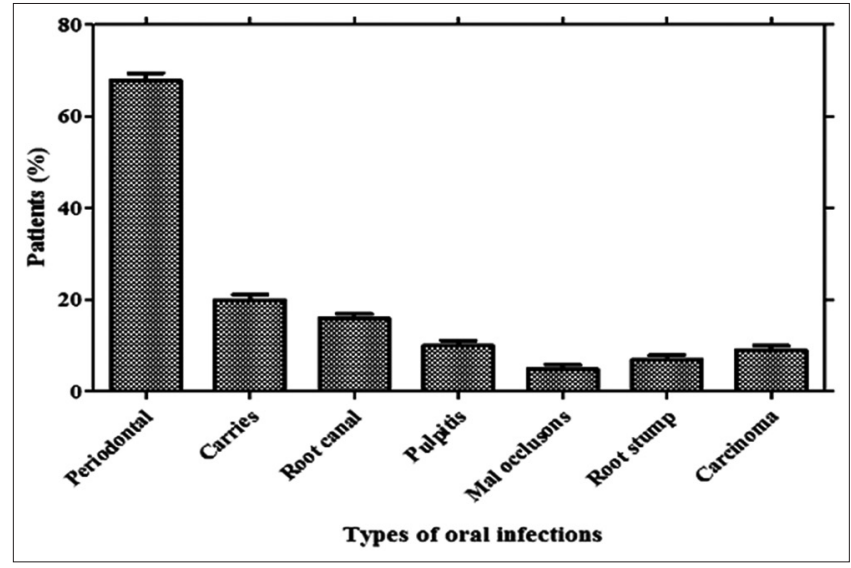

Fig. 1: Distribution of types of dental infections

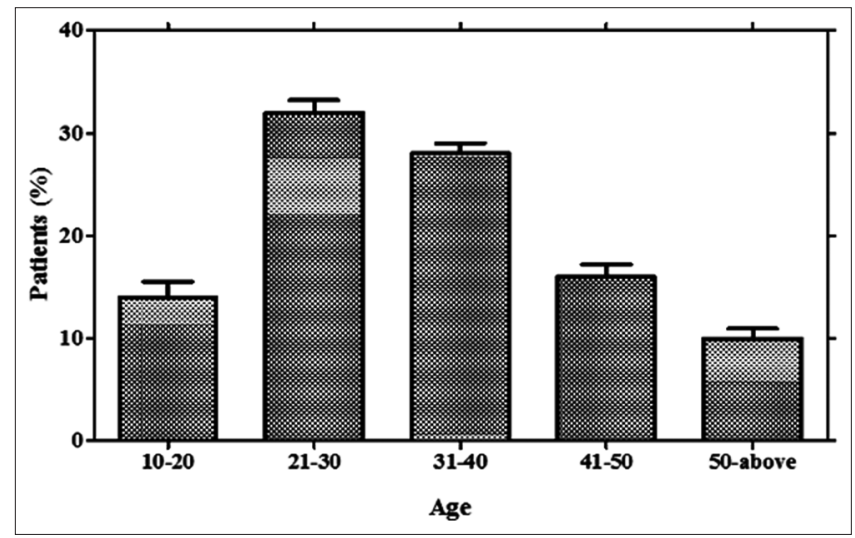

Fig. 2: Age wise distribution pattern of dental infections

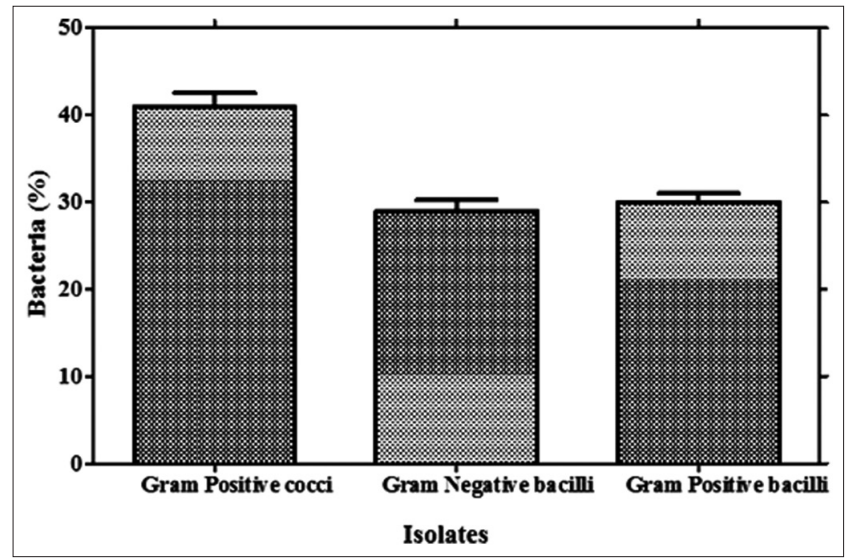

Fig. 3: Growth patterns of bacterial isolates in oral infections

Since the level of individual oral hygiene was directly related to the amount of plaque buildup on the teeth, it was reasonable to predict that the level of oral hygiene in a population was positively correlated with the prevalence and severity of periodontal disease and dental caries [8]. Hence, an understanding of the regional etiological agents was important in the management of this disease [9]. This study was undertaken to identify the both bacterial and fungal an etiology and the in vitro antimicrobial susceptibility pattern of the pathogen to commonly used antimicrobial agents. Polymicrobial nature of these dental infections has been brought out in this study.

The microbiological investigations were carried out, and a total of 55 bacterial and 10 fungal isolates were isolated from the infected 
Table 1: Demographic details, clinical types of dental infections and isolated microbes

\begin{tabular}{|c|c|c|c|c|c|c|c|}
\hline $\begin{array}{l}\text { Sample } \\
\text { No. }\end{array}$ & Date & Name & Patient No & $\begin{array}{l}\text { Symptomatic oral } \\
\text { infections }\end{array}$ & Age & Sex & $\begin{array}{l}\text { Identified } \\
\text { microorganisms }\end{array}$ \\
\hline 1 & $1-2-2013$ & Vengadesh & 091 & Gingivitis & 31 & M & $\begin{array}{l}\text { Bacillus sp., } \\
\text { Micrococcus sp. }\end{array}$ \\
\hline 2 & $1-2-2013$ & Kalavathi & 2404 & Carries & 45 & $\mathrm{~F}$ & $\begin{array}{l}\text { Staphylococcus aureus, } \\
\text { Micrococcus sp. }\end{array}$ \\
\hline 3 & $1-2-2013$ & Soundarya & 581 & RTC & 19 & $\mathrm{~F}$ & Bacillus sp. \\
\hline 4 & $1-2-2013$ & Ramayee & 98 & Carcinoma & 60 & $\mathrm{~F}$ & Micrococcus sp. \\
\hline 6 & $1-2-2013$ & Murugan & 99 & Gingivitis & 30 & M & Bacillus sp. \\
\hline 7 & $1-2-2013$ & Lakshmi & 105 & Carries & 55 & $\mathrm{~F}$ & Klebsiella sp. \\
\hline 8 & $1-2-2013$ & Dharshni & 107 & Carries & 12 & $\mathrm{~F}$ & Listeria sp. \\
\hline 9 & $1-2-2013$ & Jothi & 108 & Carries & 27 & $\mathrm{~F}$ & Bacillus sp. \\
\hline 10 & $1-2-2013$ & Sekar & 116 & Carries & 53 & M & S. aureus \\
\hline 11 & $8-2-2013$ & Muthu & 389 & Carries & 40 & M & Klebsiella sp \\
\hline 12 & 8-2-2013 & Kannammal & 2809 & $\begin{array}{l}\text { Chronic } \\
\text { periodontitis }\end{array}$ & 40 & $\mathrm{~F}$ & $\begin{array}{l}\text { Micrococcus sp., } \\
\text { Lactobacillus sp. }\end{array}$ \\
\hline 13 & 8-2-2013 & Tamilselvi & 2396 & $\begin{array}{l}\text { Chronic } \\
\text { periodontitis }\end{array}$ & 26 & $\mathrm{~F}$ & S. aureus \\
\hline 14 & $8-2-2013$ & Prathab Kumar & 2340 & Carries & 20 & M & No growth \\
\hline 15 & $8-2-2013$ & Kuttiraj & 827 & Carries & 40 & M & P. aeruginosa \\
\hline 16 & $8-2-2013$ & Sakthivel & 798 & $\begin{array}{l}\text { Chronic } \\
\text { periodontitis }\end{array}$ & 32 & M & Micrococcus sp. \\
\hline 17 & 8-2-2013 & Murugan & 99 & $\begin{array}{l}\text { Chronic } \\
\text { periodontitis }\end{array}$ & 30 & M & Micrococcus sp. \\
\hline 18 & $8-2-2013$ & Kathavarayan & 833 & Periodontitis & 27 & M & P. aeruginosa \\
\hline 19 & $8-2-2013$ & Annadurai & 834 & $\begin{array}{l}\text { Chronic } \\
\text { periodontitis }\end{array}$ & 40 & M & No growth \\
\hline 20 & $8-2-2013$ & Selvaraj & 835 & Pericornlitis & 42 & M & P. aeruginosa \\
\hline 21 & $15-2-2013$ & Pushpa & 1206 & $\begin{array}{l}\text { Chronic } \\
\text { periodontitis }\end{array}$ & 25 & $\mathrm{~F}$ & Micrococcus sp. \\
\hline 22 & $15-2-2013$ & Abdhul Rahim & 1645 & Periodontitis & 22 & M & No growth \\
\hline 23 & $15-2-2013$ & Latha & 1620 & Root stump & 38 & $\mathrm{~F}$ & Bacillus sp. \\
\hline 27 & $15-2-2013$ & Mahalakshmi & 1183 & $\begin{array}{l}\text { Apical } \\
\text { periodontitis }\end{array}$ & 36 & $\mathrm{~F}$ & $\begin{array}{l}\text { P. aeruginosa, } \\
\text { Micrococcus sp. }\end{array}$ \\
\hline 28 & $15-2-2013$ & Priya Darsini & 1648 & $\begin{array}{l}\text { Apical } \\
\text { periodontitis }\end{array}$ & 30 & $\mathrm{~F}$ & S. aureus \\
\hline 29 & $15-2-2013$ & Bhuvaneshwaran & 816 & Gingivitis & 23 & M & Bacillus sp. \\
\hline 30 & $15-2-2013$ & Muthusamy & 8422 & Mol occlusion & 24 & M & $\begin{array}{l}\text { P. aeruginosa, } \\
\text { Micrcoccus sp. }\end{array}$ \\
\hline 31 & $15-2-2013$ & Sivakumar & 942 & Gingivitis & 29 & M & S. epidermidis \\
\hline 32 & $15-2-2013$ & Selvi & 539 & RTC & 48 & $\mathrm{~F}$ & $\begin{array}{l}\text { Klebsiella sp., } \\
\text { Bacillus sp. }\end{array}$ \\
\hline 33 & $22-2-2013$ & Nafila & 1437 & Periodontitis & 24 & $\mathrm{~F}$ & No growth \\
\hline 34 & $22-2-2013$ & Nagaraj & 2176 & Periodontitis & 42 & M & P. aeruginosa \\
\hline 35 & $22-2-2013$ & Vijayalakshmi & 3160 & Periodontitis & 40 & $\mathrm{~F}$ & S. aureus \\
\hline 36 & $22-2-2013$ & Arunkumar & 2467 & Gingivitis & 21 & M & $\begin{array}{l}\text { Klebsiella sp., } \\
\text { Bacillus sp. }\end{array}$ \\
\hline 37 & $22-2-2013$ & Logabharani & 457 & $\begin{array}{l}\text { Periapical } \\
\text { periodontitis }\end{array}$ & 15 & $\mathrm{~F}$ & S. aureus \\
\hline 38 & $22-2-2013$ & Victoriya & $2665 / 1 / 13$ & Periodontitis & 32 & $\mathrm{~F}$ & No growth \\
\hline 39 & $22-2-2013$ & Padmavathi & 2477 & Pulpitis & 42 & $\mathrm{~F}$ & $\begin{array}{l}\text { P. aeruginosa, } \\
\text { S. epidermidis }\end{array}$ \\
\hline 40 & $22-2-2013$ & Annaporani & 1995 & Periodontitis & 39 & $\mathrm{~F}$ & No growth \\
\hline 41 & $22-2-2013$ & Vadivel & 2461 & Periodontitis & 43 & M & $\begin{array}{l}\text { P. aeruginosa, } \\
\text { Micrococcus sp. }\end{array}$ \\
\hline 42 & $22-2-2013$ & Dhanapriya & 1506 & $\begin{array}{l}\text { Periapical } \\
\text { periodontitis }\end{array}$ & 16 & $\mathrm{~F}$ & Bacillus sp. \\
\hline 43 & $1-3-2013$ & Sabitha & 589 & Periodontitis & 20 & $\mathrm{~F}$ & $\begin{array}{l}\text { Klebsiella sp., Bacillus } \\
\text { sp. }\end{array}$ \\
\hline 44 & $1-3-2013$ & Poongodi & 3279 & $\begin{array}{l}\text { Apical } \\
\text { periodontitis }\end{array}$ & 36 & $\mathrm{~F}$ & No growth \\
\hline 45 & $1-3-2013$ & Ganeshan & 92 & $\begin{array}{l}\text { Generalized } \\
\text { periodontitis }\end{array}$ & 57 & M & Klebsiella sp. \\
\hline
\end{tabular}


Table 1: (Continued)

\begin{tabular}{|c|c|c|c|c|c|c|c|}
\hline $\begin{array}{l}\text { Sample } \\
\text { No. }\end{array}$ & Date & Name & Patient No & $\begin{array}{l}\text { Symptomatic oral } \\
\text { infections }\end{array}$ & Age & Sex & $\begin{array}{l}\text { Identified } \\
\text { microorganisms }\end{array}$ \\
\hline 46 & $1-3-2013$ & Rajendran & 94 & $\begin{array}{l}\text { Generalized } \\
\text { periodontitis }\end{array}$ & 50 & M & S. aureus \\
\hline 47 & $1-3-2013$ & Chandra Sekar & 1655 & Gingivitis & 22 & M & S. epidermidis \\
\hline 48 & $1-3-2013$ & Kathirvel & 2380 & Periodontitis & 46 & M & Bacillus sp. \\
\hline 49 & $1-3-2013$ & Ananda Kumar & 1031 & $\begin{array}{l}\text { Apical } \\
\text { periodontitis }\end{array}$ & 20 & M & Bacillus sp. \\
\hline 50 & $1-3-2013$ & Raja & 3255 & Carris & 38 & M & $\begin{array}{l}\text { Klebsiella sp., } \\
\text { P. aeruginosa }\end{array}$ \\
\hline
\end{tabular}

S. aureus: Staphylococcus aureus, P. aeruginosa: Pseudomonas aeruginosa, S. epidermidis: Staphylococcus epidermidis, RTC: Randomized controlled trial

Table 2: Antibiotic sensitivity test

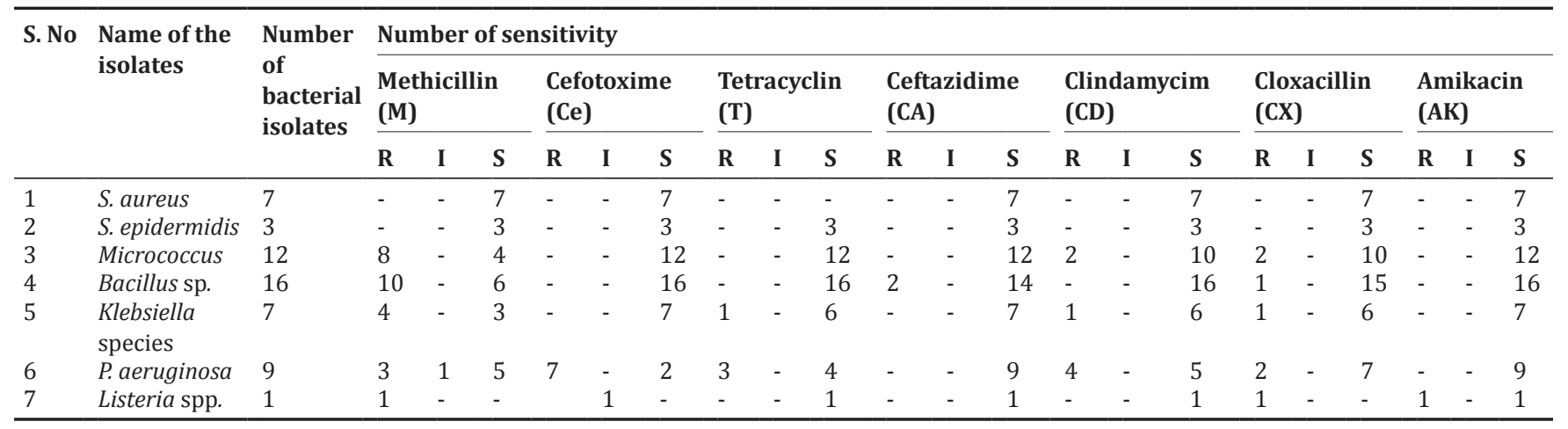

S. aureus: Staphylococcus aureus, P. aeruginosa: Pseudomonas aeruginosa, S. epidermidis: Staphylococcus epidermidis

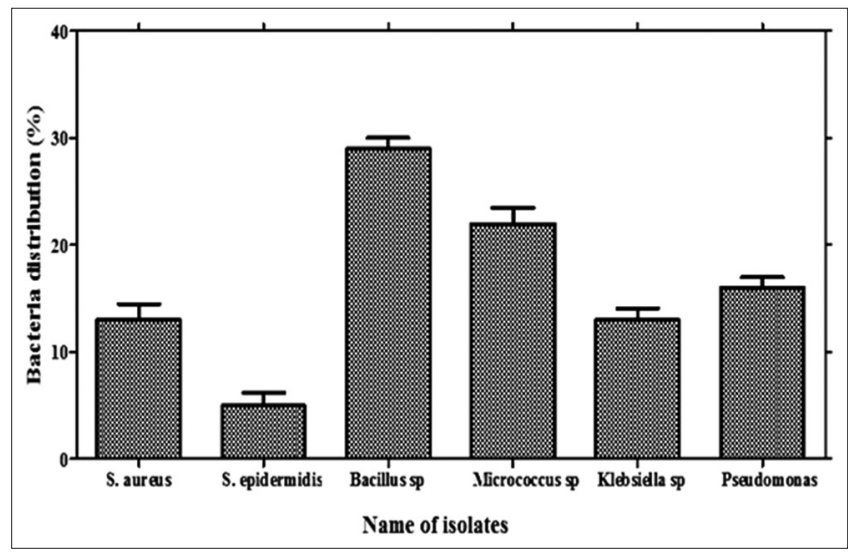

Fig. 4: Bacterial distribution among dental infections

oral patients [10]. Among 50 patients, 27 (54\%) were males and $23(46 \%)$ were females. Hence, the male showed a high predominance of dental infections than females. This was because of tobacco smoking was significantly more incident in men than females which was a possible explanation of the detected differences. On the other hand, no specific gender differences in the incidence or severity of gingival and periodontal diseases were detected [11]. Besides carries, gingivitis and periodontitis are the most frequently diagnosed oral diseases in hospitals. A total of 50 patients with oral infected patients of which, $34(68 \%)$ patients had periodontal, $10(20 \%)$ had carries lesions, $2(4 \%)$ had root canal, $1(2 \%)$ had pulpitis, $1(2 \%)$ had malocclusions, $1(2 \%)$ had root stump, and the remaining $1(2 \%)$ had carcinoma of oral infections. The percentage of periodontal infection was found to be higher than that of other oral infection $[12,13]$. The prevalence of $21-25 \%$ of conditions including pulpitis, dent alveolar abscess, periodontitis, and each other accounts for $<5 \%$.

Age seems to play an important role in the pathology of oral diseases. Out of 50 patients, $7(14 \%)$ were between the age of 10 and 20 years,
$16(32 \%)$ were between the age of 21 and 30 years. From 31 to 40 years, $14(28 \%)$ patients were infected, $8(16 \%)$ were between 41 and 50 years, and remaining $5(10 \%)$ were between above 50 . In this study, the patients above the age group of 21-30 years were most significantly infected with oral infections. That the risk of suffering from oral diseases increases with age from $14.5 \%$ at $10-19$ years to $100 \%$ at 50 years and above $[14,15]$. Oral microorganisms are generally organized in biofilms that are, based on the location relative to the gum line, divided into supragingival and subgingival plaque [16]. The periopathogenic bacteria of the subgingival plaque were considered to be the primary etiological factor of periodontitis. Among 55 bacterial isolates, 22 (41\%) were Gram-positive cocci, 17 (29\%) were Gram-negative bacilli, and the remaining 16 (30\%) were Gram-positive bacilli. Hence, the percentage of Gram-positive cocci was predominately higher than that of Gramnegative bacilli and Gram-positive bacilli [17]. Normal flora was predominated by Gram-positive cocci followed by Gram-positive bacilli. The most frequent bacteria associated with the oral infections were Bacillus 16 (29\%) followed by Micrococcus spp. 12 (22\%), Klebsiella spp. 7 (13\%), S. aureus 7 (13\%), Staphylococcus epidermidis 3 (5\%), and Listeria spp. 1 (1.8\%). Hence, Bacillus spp. were predominately present in the oral infections. S. epidermidis, C. albicans, S. aureus, and $P$. aeruginosa to be the predominant sub gingival microorganisms associated with acute exacerbations of chronic periodontal disease. The standard treatment of periodontal disease was centered on the mechanical removal of dental plaque, as well as calculus and other contaminants from tooth and root surfaces. However, this mechanical treatment was not always effective $[8,13,18]$.

Hence, the antimicrobial sensitivity pattern varies from community to community. This was because of the resistant strains as a result of indiscriminate use of antibiotics. The antimicrobial susceptibility test for S. aureus showed $100 \%$ sensitive to methicillin, ceftazidime, clindamycin, amikacin, cloxacillin, and cefotaxime but Bacillus spp. was resistant to cloxacillin and Micrococcus spp. showed resistant to both cloxacillin and clindamycin. Gram-negative isolates, Klebsiella spp. and Pseudomonas spp., were highly resistant to clindamycin, cloxacillin, and tetramycin but sensitive to amikacin. 


\section{CONCLUSION}

This study is a pilot study conducted over a period of 3-month from January 15, 2013, to April 8, 2013, at JKKK Nataraja Dental College, Komarapalayam, Namakkal, Tamil Nadu, India. In this study, the patients with different types of dental problems were screened for their microbiological profile. Their antibiotic pattern was also ascertained. In this study, there was a higher predominance of Grampositive cocci accounting for $22(41 \%)$ cases followed by Gram-negative bacilli accounting for 17 (29\%) cases. In this study, male showed a high predominance of oral infections than females. The pattern of patient's distribution of different types of dental infection showed that patients with periodontal infection were found to be higher than that of any other oral infection. The age distributions of patients showed that patients in the age group of 21-30 years were more affected by dental problems followed by the age group of 31-40 years. The major reason attributing to such a cause is improper tooth care, smoking, and usage of carbonated drinks. The most frequent and predominant bacteria associated with dental infections were Bacillus spp. followed by Micrococcus spp. and Klebsiella spp. The antibiotic sensitivity pattern showed $S$. aureus sensitive to methicillin, ceftazidime, clindamycin, amikacin, cloxacillin, and cefotaxime, while Gram-negative isolates like Klebsiella spp. and Pseudomonas spp. were highly resistant to clindamycin, cloxacillin, and tetracycline but sensitive to amikacin. In conclusion, this study highlights the different organisms involved in the different types of dental infections. The antibiotic pattern shown in this work will be a guide to the clinician in the selection of proper antibiotics for the treatment of these infections. Hence in this study, the limitations were time and the number of patients. For better outcomes, a larger study population for a longer period of time should be undertaken to know the bacteriology and to the select the effective drugs of choice for dental infections. A comparative study of bacteriology and mycology and its antimicrobial property would be very fruitful in the future.

\section{REFERENCES}

1. Emes Y, Buket A, Serhat Y. On the evolution of human jaws and teeth: A review. Bull Int Assoc Paleodont 2011;5(1):37-47.

2. Metivier A, Bland K. Dental Anatomy: A Review. Crest Oral-B Continuing Education Course. 2013. p. 1-23. Available from: http:// www.dentalcare.com. [Last accessed on $2013 \mathrm{Apr}$ 23].

3. Kuramitsu HK, He X, Lux R, Anderson MH, Shi W. Interspecies interactions within oral microbial communities. Microbiol Mol Biol Rev 2007;71(4):653-70

4. Gonzales-Marin C, Spratt DA, Millar MR, Simmonds M, Kempley ST,
Allaker RP. Levels of periodontal pathogens in neonatal gastric aspirates and possible maternal sites of origin. Mol Oral Microbiol 2011;26(5):277-90.

5. Karnure M, Munot N. Review on conventional and novel techniques for treatment of alveolar osteitis. Asian J Pharm Clin Res 2013;6(3):13-7.

6. Bastos JA, Diniz CG, Bastos MG, Vilela EM, Silva VL, Chaoubah A, et al. Identification of periodontal pathogens and severity of periodontitis in patients with and without chronic kidney disease. Arch Oral Biol 2011;56(8):804-11.

7. Bauer AW, Kirby WM, Sherris JC, Turck M. Antibiotic susceptibility testing by a standardized single disk method. Am J Clin Pathol 1966;45(4):493-6.

8. Weyrich LS, Dobney K, Cooper A. Ancient DNA analysis of dental calculus. J Hum Evol 2015;79:119-24.

9. Janatová T, Najmanová L, Neubauerová L, Kyselková M, Novotná G, Spízek J, et al. Changes in the incidence of periodontal pathogens during long-term monitoring and after application of antibacterial drugs. Folia Microbiol (Praha) 2009;54(5):429-35.

10. Prasad KV, Anupama I, Rao N, Sreenivasan PK, Subramanyam R, Kulkarni RD. The effect of the dentifrice on gingivitis and dental plaque: A 6-week clinical study in India. J Indian Assoc Public Health Dent 2015;13:4-10.

11. Chukhlovin AB, Solovyova AM, Matelo SK, Kobiyasova IV, Morosova EB, Hokhlacheva AV, et al. Bacterial markers of periodontal diseases and their practical significance in dentistry. Bull Exp Biol Med 2007;144(4):546-50.

12. Santhosh-Kumar MP, Harshini AK. Knowledge and awareness about oral cancer among undergraduate dental students. Asian J Pharm Clin Res 2016;9(4):1-3.

13. Supranoto SC, Slot DE, Addy M, Van der Weijden GA. The effect of chlorhexidine dentifrice or gel versus chlorhexidine mouthwash on plaque, gingivitis, bleeding and tooth discoloration: A systematic review. Int J Dent Hyg 2015;13(2):83-92.

14. Antipa C, Dascalu L, Chifiriuc MC, Lazar V, Bleotu CC, Ruta SM. Isolation, identification and antibiotic susceptibility profiles in bacterial strains isolated from periodontal lesions. Ann Biol Res 2014;5(3):22-6.

15. He XS, Shi WY. Oral microbiology: Past, present and future. Int J Oral Sci 2009;1(2):47-58.

16. Ranganathan K, Magesh KT, Kumarasamy N, Solomon S, Visvanathan R, Johnson NW. Greater severity and extent of periodontal breakdown in 136 South Indian human immunodeficiency virus seropositive patients than in normal controls: A comparative study using community periodontal index of treatment needs. India J Dent Res 2007;18(2):55-9.

17. Saini S, Aparna, Gupta N, Mahajan A, Arora DR. Microbial flora in orodental infections. Indian J Med Microbiol 2003;21(2):111-4.

18. Peciuliene V, Reynaud $\mathrm{AH}$, Balciuniene I, Haapasalo $\mathrm{M}$. Isolation of yeasts and enteric bacteria in root-filled teeth with chronic apical periodontitis. Int Endod J 2001;34(6):429-34. 